\title{
CONSTRUCTION LABOUR PRODUCTIVITY FACTORS IN DEVELOPING CITY. CASE STUDY: GWALIOR
}

\author{
Rohit Trivedi ${ }^{1}$, Mukesh Pandey ${ }^{2}$ \\ ${ }^{I}$ M.Tech. Student Civil Department ITM University, Gwalior \\ ${ }^{2}$ Professor and Head of Civil Engineering Department ITM University, Gwalior
}

\begin{abstract}
As we know India is a developing country and there are many developing cities in it. Gwalior (M.P.) is one of the developing cities of India. Many construction projects and industries getting their way to Gwalior for their project and construction labour productivity is became highly important issue now days, because to complete construction projects on time we have to know about the labour productivity factors in particular area. The main objective of this study is to give the possible factors that affect the construction labour productivity in Gwalior. On the basis of previous study, questionnaire forms were developed and there are 26 factors on it, after that we went on approximately every construction projects which are running in Gwalior and find the most appropriate factors that affects construction labour productivity in Gwalior. Then after the RII analysis, we ranked each and every factor on the basis of data collected by Project Managers, Project Co-ordinator, Site Engineer's. These are some top rated factors such as: (1) Payment delays; (2)Working overtime; (3)Inefficiency of equipment; (4)Material shortage; (5)Labour absenteeism; (6)Lack of financial motivation system; (7)Tool and equipment shortages; (8)Lack of labour experience; (9)Drawings and specifications alternated during execution; (10)Increasing number of labourers; (11)Rework, This data will be beneficial for the professionals to keep these factors in mind when scheduling their construction project in Gwalior
\end{abstract}

\section{INTRODUCTION}

In construction field there is nothing which we can surely predict in earlier, but still on the basis of research and innovations we can remove most of the factors which can affect our construction projects, construction labour productivity is one of them. There are many research work is already done on the field of labour productivity but still the problems are coming, one of the reasons of these problems is the construction labour productivity is basically depends on the area. Because on the basis of a countries productivity factor one cannot judge the conditions to the particular area, so the area wise factors are very important. Because there are many different types of things which changes area wise like behaviour, mentality and working conditions. As we know Gwalior is now becoming smart city now a days and many construction firms and corporate professionals are interested to invest in construction field in Gwalior.

The developing city plays a vital role to the growth of a country and Gwalior is one of them but the conditions in Gwalior are different than the other cities, because it has different weather conditions, different working scenario, and different mentality level of people as well. So knowing about Gwalior's construction labour productivity is very important to the future prospective.

Construction industry is mainly depends on the sources provided by the participant, the more you give the resources to the project like manpower, machine and material, it become easier to complete the project with in the scheduled time. In this the manpower is the most significant factor on which construction industry is more and more dependent, and in terms of construction projects the manpower connects with labour productivity, which is the biggest concern in the project point of view.

On the basis of literature survey some basic idea about the labour productivity is came out, mentioned are some view of researcher on labour productivity:

1. According to Richard L. Tucker "to improve productivity attention must be focused on the management issue".

2. Polat and Arditi (2005) states that "to improve productivity different policies are to be adopt for different countries because they are not similar".

3. Adrian (1987) defines that "to improve labour productivity firstly improve the basic factor which effects labour productivity like; union legacy, seasonality, motivational factor, management etc.

4. Olomolaiye (1987) classified productivity factors into two major categories;

a. External factors (outside control)

b. Internal Factors (inside control)

Factors affecting labour productivity based on research and literature survey:

S. No. Factors affecting Labour Productivity

1 Accidents

2 Construction method

3 Drawings and specifications alternated during execution

4 Government regulation

5 High quality of required work

6 Increasing number of labourers 
7 Inefficiency of equipment

8 Inspection delay

9 Insufficient transportation mean

10 Insufficient lighting

11 Labour absenteeism

12 Labour disloyalty

13 Lack of competition

14 Lack of financial motivation system

15 Violation of safety precautions

16 Weather change

17 Working at high places

18 Working overtime

19 Payment delays

20 Rework

21 Material shortage

22 Lack of training sessions

23 Tool and equipment shortages

24 Lack of labour experience

25 Lack of periodic meeting with labour

26 Labour personal problems

\section{METHODOLOGY AND ANALYSIS}

The methodology opted for this research paper is questionnaire survey. The form is generated which contains 26 factors which affect the construction labour productivity(based on literature survey). Then after creating the questionnaire form we went almost all the construction site in Gwalior and also meet the professionals outside, on the basis of their experience and knowledge they ranked our factors according to their perception how they think about the factor or where it exist on the ordinary scale from 1 to 5 . All the projects from where we collected data are residential building projects.

After meeting 23 professionals i.e. Project manager, Project Co-ordinator, Owner's and Site Engineers. We collected the form in which they ranked the factors $1-5$. The scale shows in table 1.1 , represents value 1-5 with types of effect.

Table: Shows Value with Effect

\begin{tabular}{|l|c|}
\hline \multicolumn{1}{|c|}{ Item } & Scale \\
\hline Not applicable & 1 \\
\hline Does not affect it & 2 \\
\hline Somewhat affects it & 3 \\
\hline Directly affects it & 4 \\
\hline Mostly affects it & 5 \\
\hline
\end{tabular}

When we collected data on the ordinary scale ranking 1-5, then we used Relative Importance Index (RII) for the analysis of the data. RII is mostly used to decide the professional's opinions in research work. A RII calculation formula with the notations is stated below:

$\boldsymbol{R} \boldsymbol{I}=\frac{\left(5 * \mathrm{~N}_{5}+4 * \mathrm{~N}_{4}+3 * \mathrm{~N}_{3}+2 * \mathrm{~N}_{2}+\mathrm{N}_{1}\right)}{\left(5 *\left(\mathrm{~N}_{1}+\mathrm{N}_{2}+\mathrm{N}_{3}+\mathrm{N}_{4}+\mathrm{N}_{5}\right)\right)}$

$\mathrm{N}_{1}=$ Not applicable

$\mathrm{N}_{2}=$ Does not affect it

$\mathrm{N}_{3}$ = somewhat affects it

$\mathrm{N}_{4}=$ directly affects it

$\mathrm{N}_{5}=$ Mostly affects it

* RII values always lies between 0 to 1 . $(0<$ RII $>1)$

\section{RESULTS AND DISCUSSION}

After doing RII calculations the RII values are came out for the each factor. So based on the RII values we ranked the factors here are the list of top 11 factors that mostly affect the construction labour Productivity:

\begin{tabular}{|l|l|l|}
\hline FACTORS & RII & RANKING \\
\hline Payment delays & 0.783 & 1 \\
\hline Working overtime & 0.739 & 2 \\
\hline Inefficiency of equipment & 0.704 & 3 \\
\hline Material shortage & 0.678 & 4 \\
\hline Labour absenteeism & 0.670 & 5 \\
\hline Lack of financial motivation system & 0.662 & 6 \\
\hline Tool and equipment shortages & 0.661 & 7 \\
\hline Lack of labour experience & 0.621 & 8 \\
\hline Drawings and specifications alternated during execution & 0.617 & 9 \\
\hline Increasing number of labourers & 0.609 & $10^{*}$ \\
\hline Rework & 0.609 & $11^{*}$ \\
\hline
\end{tabular}

After getting highest RII value 0.783, Payment delay is ranked as no. 1 factor; which affect construction labour productivity in Gwalior.so it is most important thing to be consider when the project is going to schedule in Gwalior, so that sufficient fund is to be generated before starting the construction project so that not to delay in payments will occur.

Working overtime is ranked as factor no. 2 after getting RII value 0.739 ; it means the working capacity of the labour 
should be kept in when project is proposed. Similarly insufficiency of equipment ranked as factor no 3 on the basis of RII value 0.704 ; so the equipment's are also playing a vital role to affect the construction labour productivity.

Material is one of the key factors in construction because insufficiency of material can cause a huge loss in productivity, therefore Shortage of material is ranked as factor no. 4 and RII value is 0.678 .

Labour absenteeism ranked as factor no 5 with RII value 0.670 ; so the particular days should be off to work. This factor can create huge loss in labour productivity. Similarly Lack of financial motivational system got the ranking 6 with RII value 0.662; so if some motivational schemes are to be designed to motivate workers, it can improve the construction labour productivity.

Tools and Equipment shortage is got $7^{\text {th }}$ rank with RII value 0.661.it shows that the tools and equipment shortage is one of the major aspect in Gwalior that affects labour productivity. So proper arrangement of tools and equipment are necessary.

Lack of labour experience is factor no 8 with RII value 0.621. it means to appoint a skilled and experienced worker for the particular task is also a big challenge for the management.

On rank no 9, with RII value 0.617; Drawings and specifications alternated during execution is the factor, it shows that clarification or neatness is required in given drawing or given work.

There are two factors who got the RII value 0.609; but one ranked up and the other one is ranked below. As we can see Increasing number of labourers and Rework got the RII value 0.609 but ranked as $10^{\text {th }}$ and $11^{\text {th }}$ respectively, because the factor on ranked no. 10 is got more N5 value in comparison of factor on ranked 11, so that they are ranked as stated. And increase in number of labour and Rework, these two factors are creating big effect on labour productivity in Gwalior.

\section{CONCLUSION AND RECOMMENDATION}

The prior knowledge of every subject is beneficial all the time, and for Gwalior city this study on labour productivity will give too much benefit to the owners and management too. After considering the mentioned factor, in the construction project there will be increase in productivity and because of this improvement in labour productivity, it will be helpful to save time and cost also.

Below are some recommendations for the improvement of construction labour productivity in Gwalior:

I. The payment delay should not be happened on the construction projects. Because worker or labours which works on site are very much needed the money, a study tells that $70 \%$ of the labour earns money every day and purchase the daily grocery to cook food. It simply means they don't have enough money to survive without payment, so if a new construction project is about to start in Gwalior so they have to be in mind that they have enough money to give payments on time to complete their project on time.

II. The construction organisations should be keep in mind that the working overtime can reduce the labour productivity, so they have to prepare a cycle of labours or workers to not to put too much load, this strategy will help to improve labour productivity.

III. It is desirable that the construction equipment's been efficient and give their best result at the time of performance to reach the desired productivity.

IV. The material management team should have aware about the material stocking, because the material shortage can also cause the lower labour productivity.

V. To achieve desired results, the labour contractor or the manager who recruit the labour should keep one thing in mind that the labour which they recruit should be punctual and not absent in one or two day of interval and to avoid Absenteeism at work site can be reduced with inclusion of appropriate paid time off and vacations to all employees.

VI. A financial incentive or any financial motivational system in the form of best employee or worker of the year should be implemented to create competition among the employees, thus achieving better productivity.

VII. The tools and equipment's are one of the best buddies of labour or worker, so the manager should aware about the tolls and equipment's, shortage of these thing can reduce their expected result.

VIII.Complex design and incomplete drawings specifications should be avoided and care should be taken to avoid confusion among the various construction agencies.

\section{REFERENCES}

[1]. Abdul Kadir, M. R., Lee, W. P., Jaafar, M. S., Sapuan, S. M., and Ali, A. A. (2005). "Factors affecting construction labor productivity for Malaysian residential projects." Structure Survey, 23(1), 42-54.

[2]. Adrian, J. (1987). Construction Productivity Improvement. Elsevier Science Publishing, Amsterdam, Netherlands.

[3]. Bramble, B. B., and Callahan, M. T. (2000). Construction Delay Claims. Aspen Publishers.

[4]. Cheung, S. O., Suen, H. C. H., and Cheung, K. K. W. (2004). "PPMS: A web-based construction project performance monitoring system." Automation in Construction, 13(3), 361-376.

[5]. Drewin, F. J. (1982). Construction Productivity: Measurement and Improvementthrough Work Study, Elsevier Science Ltd., NewYork.

[6]. Enshassi, A., Al-Hallaq, K. and Mohamed, S. (2006). "Causes of contractor's business failure in developing countries: The case of Palestine." Journal of Construction in Developing Countries, 11(2), 1-14.

[7]. Halligan, D. W., Demsetz, L. A., Brown, J. D., and Pace, C. B. (1994). "Action-response models and loss 
of productivity in construction." Journal of Construction Engineering Management, 120(1), 47-64.

[8]. Hanna, A. S., and Heale, D. G. (1994). "Factors affecting construction productivity: Newfoundland versus rest of Canada." Canadian Journal of Civil Engineering, 21(4), 663-673.

[9]. Harris, F, Holt, G., Kaming, E., and. Olomolaiye, P. (1998). "Factors influencing craftsmen's productivity in Indonesia." International Journal of Project Management, 15(1), 21-30.

[10].Jarkas, A. M. (2005). "An investigation into the influence of build-ability factors on productivity of in situ reinforced concrete construction." Ph.D. thesis, University of Dundee, Dundee, UK.

[11].Olomolaiye, P. O., Wahab, K., and Price, A. (1987). "Problems influencing craftsman productivity in Nigeria." Building Environment, 22(4), 317-323.

[12].Polat, G., and Arditi, P. (2005). "The JIT Management System in developing countries." Construction Management and Economics, 23(7), 697-712.

[13].Portas, J., and AbouRizk, S. (1997). "Neural network model for estimating construction productivity." Journal of Construction Engineering and Management, December, 399-410.

[14].Richard L. Tucker,1 F. Management of construction productivity ASCE Journal of Management in Engineering, Vol. 2, No. 3, July, 1986. CASCE, Tucker, R. (1986). "Management of Construction Productivity." J. Manage. Eng., 10.1061/(ASCE)9742597X (1986)2:3(148), 148156. TECHNICAL PAPERS Management of Construction Productivity Article History Published: 01 July 1986 Publication Data ISSN (print): 0742597X ISSN (online): 19435479 Publisher: American Society of Civil Engineers Richard L. Tucker, F. ASCE1 1C. T. Wells, Prof. of Proj. Management, Dept. of Civ. Engrg., Univ. of Texas at Austin, Austin, TX 78712 